\title{
The Development Strategy of County Characteristic Culture Industry in Hebei Province Based on SWOT Analysis
}

\author{
Wang Lixin \\ Sifang institute of Shijiazhuang railway university \\ Shijiazhuang, China \\ 58429562@qq.com
}

Gan Xiuna

Sifang institute of Shijiazhuang railway university

Shijiazhuang, China

\author{
Wang Suchao \\ Sifang institute of Shijiazhuang railway university \\ Shijiazhuang, China
}

\begin{abstract}
The development of cultural industry is an important symbol of the development of a province and a city, but also an important embodiment of its cohesion and creativity.In view of the present situation of Hebei Province, this paper emphatically analyzes the strengths (S)of county in hebei province characteristic culture, weaknesses $(\mathrm{W})$ and the opportunities $(O)$ and threats $(T)$, Deepening people's understanding of the development of cultural resources. It also puts forward some measures to solve the problems of the development of county characteristic culture industry in Hebei province. At the same time, it also provides a reference for other areas with rich cultural resources, but the development is not perfect.
\end{abstract}

Keywords-Hebei province; County; Characteristic culture industry; SWOT analysis

SiMaqian's historical records, such a word, "county and county, the county set and the world, county government, a world without treatment," which is sufficient to illustrate the importance of the county. The county cultural industry is an important manifestation of the overall cohesion and creativity of the county. The development of county characteristic culture industry in Hebei province is in the initial stage, and the experience of each aspect is slightly less. In addition, at present, the domestic research on this aspect is relatively deficient.County in hebei province in recent years, the characteristics of cultural industry in the process of exploration development, has made a series of achievements, the formation of a cultural tourism, special arts and crafts in driving the creative production and cultural goods manufacturing, cultural celebrity, characteristic performances and other models, and has realized the supply of cultural and economic benefits [1] .However, compared with some developed provinces, Hebei province is still in the primary stage of the characteristics culture of the county, has not become a pillar, the market development is not perfect, the people's attention is not high, the government policy is relatively slow, the talent is also relatively scarce, lack of cultural development of creative design, and so on, these are seriously restricting the development of county characteristic culture industry in Hebei province.Based on the research of the county cultural industry in Hebei Province, the paper analyzes the strengths, weaknesses, opportunities and challenges of province by using SWOT analysis method. On this basis, the paper is based on the development of county characteristic culture industry in Hebei province to identify and formulate strategic planning.

\section{THE CURRENT SITUATION OF THE DEVELOPMENT OF COUNTY CHARACTERISTIC CULTURE INDUSTRY IN HEBEI PROVINCE.}

Cultural industry in Hebei province in 2012 work is put forward, make culture industry development key (area), the cultural industry clusters, the implementation of major cultural industry projects lead the project, to advance the county territory characteristic culture industry development. So far, a batch of cultural industry in Hebei province characteristic county has begun to take shape, drive the overall development of the county economy and culture in Hebei province. For example, Zhangjiakou Yuxian vigorously develop the paper-cut as leading culture industry ; Xingtai Ningjin County painting development is swift and violent, as of 2015 on half of the output value reached 2.1 billion yuan; Shijiazhuang Gaocheng lanterns industry mainly concentrated in Tuntou Cun, known as "the first Chinese lanterns village". The village now has lanterns production enterprises, and processing households 1100 , practitioners of more than 50000 people, an annual output of palace lantern 50 million, the output value of 10 billion yuan, accounting for more than $80 \%$ of the total output of the national palace lantern. Pingxiang County, baby stroller industry sudden appearance of a new force, annual production value of more than 40 billion yuan.

In addition, Quyang stone carving, Wuqiang New Year pictures and music, Guantao black-pottery, Pingquan activated carbon, Daming straw, Wuqiao acrobatics, Chongli winter tour, a number of distinctive cultural brand has also become leader of the county cultural industry in Hebei Province. Fengning, Zhangbei, Shexian County, Qianxi, Xianghe, Yongnian and other places outstanding 
culture, tourism, ecological advantages, actively explore the integration of cultural industry and tourism fuse development.

\section{SWOT ANALYSIS OF THE DEVELOPMENT OF COUNTY CHARACTERISTIC CULTURE INDUSTRY IN HEBEI PROVINCE}

\section{A. The strengths of the development of county characteristic culture industry in Hebei Province}

\section{1) Characteristics}

Quyang stone carvings, Yuxian paper-cut, Wuqiang New Year pictures, Cangzhou martial arts, Wuqiao acrobatics has been oriented country, well-known in the country, is the outstanding representative of county of Hebei Province cultural characteristics. In addition, in other aspects of cultural resources, traditional crafts, folk art, opera culture also has a special advantage, for example: Shijiazhuang Jingxing Lahua, Cangzhou Nanpi County Lazi, Baoding Xushui Lion Dancing, Langfang Yongqing straw carving skills, Zhangjiakou Yuxian ancient residential architecture art, Baoding Yixian Yishui inkstone carving making skills, Baoding Dingzhou Yangko and opera, Zhangjiakou Kangbao Errentai and so on.

\section{2) Has a base.}

At present, Quyang sculpture Culture Industrial Park was incorporated into the National Cultural Industry Experimental Park , Hengshui Xisannei Painting Co., Ltd., Quyang hongzhou marble handicraft factory Co., Ltd. Cangzhou Suning Yuehai musical instrument Co., Ltd., 10 enterprises selected national cultural industry demonstration base.In addition, yu county paper-cut, Wuqiang New Year pictures, has become a pillar industry of local enriching people. QuYang, for example, more than 2300 existing sculpture enterprises, solve the employment of more than 100000 people, 3 billion production value, products are exported to more than 100 countries and regions ${ }^{[2]}$

\section{3) Have inside information}

Baoding, Zhengding ,Chengde, Shanhaiguan, Handan five were rated as the world's cultural city.In addition, chengde mountain resort and surrounding temples, the essence of the Great Wall of the town of Jingzhen, Baoding Yixian qing xiling, Tangshan Zunhua qingdongling, these have been included in the world cultural heritage. Tangshan Yutian clay sculpture, Shijiazhuang Xinji peasant paintings, Shijiazhuang Zhengding Changshan war drums, Cangzhou Cangxian lion dance 511 was listed as provincial intangible cultural heritage.It is clear that counties in Hebei province cultural heritage.

4) The position is superior.

Hebei province around Beijing and Tianjin, and Northeast China, North China, central China, East China, northwest five plains are connected.Among them, Zhangjiakou north of Neimeng, south of Beijing, Langfang connecting Beijing and Tianjin, occupying traffic arteries, Baoding, Cangzhou respectively with Beijing, Tianjin, Hengshui connected with big cultural province of shandong, the other cities and counties also developed and convenient transportation and Hebei has a large population is a huge potential market. These also constitute a strong advantage in the development of county culture industry in Hebei province.

\section{B. The analysis of the weakeness of the development of county characteristic culture industry in Hebei Province.}

\section{1) Brand positioning fuzzy, lack of personality}

The county characteristic culture brand should be a country culture the response, has its unique connotation, the style and the elegant demeanor, should take the personalization localization. But, at present, Hebei Province county domain culture industry in brand positioning, tend to focus on large and broad country name, but ignore the small and fine features of words. For example, Shijiazhuang Jinzhou "of Chinese pear township", Langfang city county, "the hometown of the Chinese rosewood" ,Zhangjiakou Zhangbei "ecological Zhangbei"and so on. This not only lost some of present cultural characteristics, and because of the too much and lost its appeal.

2) Talent withered, quality is low.

The development of any industry, talent is one of the indispensable elements, as well as the development of county characteristic cultural industry, also need a large number of professional and interdisciplinary talents.Currently, each county personnel engaged in this aspect both the quantity and quality all has the huge loss.Will be in Shijiazhuang, Hebei province, for example, practitioners are only about 70000 people, and as the national culture of the ancient city of Baoding, practitioners are less than 60000 . Thus in the county development characteristics of cultural industry and collect the related information, often appeared to be inadequate, creating products is also a lack of creative and not competitive. More important is to cultivate and introduce the talents in Hebei Province, and it has not formed in line with the local cultural characteristics and requirements of the training and introduction mechanism.

3) Poor investment system, not form a cultural industry chain.

The development of the industry can't depart from the support of capital, perfect investment system is the important guarantee of an industry development, also is the important pillar of the county cultural industry development.But, as a result of investment in cultural aspects, Hebei province started late, the degree of marketization is not enough, concept did not keep up with in time, so the related policy system is not perfect, the county of Hebei province culture still mainly rely on state investment, private investment occupies less than thirty percent. Although the county historical relics protection, tourism, film and television art has some development, but due to lack of funding support, also be in individual situation, no mutual support and interdependence, cannot form the industrial chain, as well as difficulty in forming the cultural brand.Zhangjiakou, for example, Zhangbei vast grasslands, good ecological environment, and the 
farming and nomadic civilization blend the unique culture, but because of their poor economic, also does not have good investment system, so that the rich resources of many haven't development, idle.Cangzhou xian, its large number of cultural relics, with the han dynasty tombs, the Ming dynasty stone bridge, zhangzhuang the Catholic church of the French gothic style of architecture, Ma Benzhai mother-child martyr cemetery, etc., but these same because of the lack of investment and didn't get due development.

\section{The opportunity analysis of the development of county characteristic culture industry in Hebei Province}

1) The arrival of the era of cultural industry development.

2009, China has promulgated the "cultural industry revitalization plan", which means that our country's cultural industry has entered a new era, the cultural industry is about to usher in a broad prospect. In recent years, Hebei Province will continue to improve the investment environment of culture industry, has formulated and sent the Hebei Province construction culture province outline, "the Hebei Province on accelerating the cultural undertakings and cultural industries a number of policy "," on the encourage social capital into the cultural industry views "and other documents, the gradual relaxation of the cultural industry standard threshold ${ }^{[3]}$.In particular, this year, the investment adviser released the "2015 - 2019 Hebei Province cultural industry investment analysis and forecast report", in order to promote the development of the county characteristics cultural industry in Hebei province to provide a strong impetus.

2) The coordinated development of beijing-tianjinhebei's arrival.

Hebei province around Beijing and tianjin, the geographical position is superior, the large population, and are of unique yanzhao culture, has huge development potential. Integration of the beijing-tianjin-hebei region again, especially the beijing-tianjin-hebei coordinated development planning outline, for the development of Hebei county characteristic culture, is a cardiotonic.

3) The arrival of the Internet era.

The rapid development of science and technology is a powerful engine to lead the industry to develop.Today, the development of the Internet is growing by leaps and bounds in our country, especially the advent of the Internet era of big data now, this directly led to the prime minister LiKeqiang, now the era characteristic extremely the strategy of "Internet + ". "Internet + " strategy for the culture industry is definitely a great opportunity, according to the "2015 thirty-fifth China Internet development status statistics report" shows that as of December 2014, China's Internet users reached 649000000 , Internet penetration rate of $47.9 \%{ }^{[4]}$.Thus, if the county characteristics cultural industry in Hebei province and the strategy of "Internet + " together, that will create a great thrust to the development of be county characteristics cultural industry in Hebei. Langfang dacheng county has become the first signing of the "Internet +" strategy of the county.

4) Animation, film and television industry era.

With the improvement of people's living standards, animation industry, film and television industry has become an indispensable part of people's life, especially now in the animation industry and film industry ushered in the peak period. In the film, the 2013 film production side of the film 638, the market has reached 21769000000 yuan, the national hero Mao Zedong, comrade Deng Xiaoping, comrade Qi Jiguang and other characters are on the screen, which provides a good reference for the development of Hebei's county characteristics cultural industry.

\section{The threat analysis of the development of county characteristic culture industry in Hebei Province.}

\section{1) The competition of regional culture.}

Zhangjiakou, Chengde, Baoding, Langfang, Tangshan and other places adjacent to Beijing and Tianjin, in the geographical position is superior, but also brings a certain threat. As is known to all, the Beijing and Tianjin culture industry is very developed area, from regional point of view, and in Hebei are of yanzhao culture, and its cultural development has been occupy the high-end market, more dynamic and competitive. In addition, other counties are close to the cultural province, such as the Hengshui, Xingtai, Handan are near the big cultural province of Shandong, causing serious impact. Cultural competition in the region is undoubtedly a big challenge to the development of the cultural industry in Hebei province.

\section{2) The competition between counties.}

Due to the Hebei Province in recent years vigorously support the development of cultural industry, the municipalities and counties to funds to the project, local counties has been in a fierce competition.Shijiazhuang Jinzhou hit, for example, "the hometown of pears in China" brand, and also the Dacheng county of Langfang ever played "the hometown of pears" slogan; Cangzhou xian as "the hometown of golden thread jujube", however, Cangxian is also regarded as "the hometown of golden thread jujube". County resources characteristics of good or bad depends on the county cultural industry development is good or bad, and the advantages and disadvantages will be continuously widening, thus, the development of the county cultural industry in Hebei province will be extremely unbalanced, would have been at a low level as a whole.

3) The competition foreign culture industry.

Along with our country reform of increasing,some of the outstanding cultural enterprises abroad into the various counties in Hebei Province, the local caused a serious impact, such as carnival, Disney and other enterprises, as well as the influx of Christmas, Valentine's day and other festivals, these are all counties to develop their own cultural industry caused a certain threat. 


\section{E. SWOT composite matrix of the development of county characteristic culture industry in Hebei Province}

Constructing the SWOT composite matrix of the development of the county characteristic culture industry in Hebei, as shown in table -1. Table- 1 transverse for Opportunity (O)and Threat (T), column for Strengths (S), Weaknesses (W), the matrix part of the table is a combination strategy.

TABLE-I SWOT ANALYSIS OF THE DEVELOPMENT OF COUNTY CHARACTERISTIC CULTURE INDUSTRY IN HEBEI

\begin{tabular}{|c|c|c|c|}
\hline \multirow{2}{*}{\multicolumn{2}{|c|}{$\begin{array}{l}\text { Internal environment } \\
\text { analysis }(\mathrm{S}, \mathrm{W}) \\
\text { External environment analysis } \\
(\mathrm{O}, \mathrm{T})\end{array}$}} & Opportunity (O) & Threat \\
\hline & & $\begin{array}{l}\text { Countries have begun to } \\
\text { pay attention to, the } \\
\text { advent of the era of } \\
\text { cultural industry; } \\
\text { Integration of the } \\
\text { beiijing-tianjin-hebei } \\
\text { region put forward } \\
\text { again, } \\
\text { beijing-tianjin-hebei } \\
\text { system development } \\
\text { policy, The boom of the } \\
\text { Internet, the } \\
\text { development of } \\
\text { animation, film and } \\
\text { television play, the } \\
\text { expansion of platform. }\end{array}$ & $\begin{array}{l}\text { Because with the } \\
\text { Beijing and Tianjin } \\
\text { Hebei province } \\
\text { belongs to the yanzhao } \\
\text { culture, regional } \\
\text { competition at a } \\
\text { disadvantage; Various } \\
\text { counties in the } \\
\text { province is in a state of } \\
\text { intense competition; } \\
\text { The invasion of } \\
\text { foreign culture. }\end{array}$ \\
\hline \multirow{2}{*}{$\begin{array}{l}\text { Strength } \\
\text { (S) }\end{array}$} & $\begin{array}{l}\text { Rich cultural } \\
\text { resources and each }\end{array}$ & $\begin{array}{l}\text { Strength Opportunity } \\
\text { Strategy }(\mathrm{S}, \mathrm{O})\end{array}$ & $\begin{array}{l}\text { Strength Threat } \\
\text { Strategy }(\mathrm{S}, \mathrm{T})\end{array}$ \\
\hline & $\begin{array}{l}\text { has its own } \\
\text { characteristics; After } \\
\text { years of } \\
\text { development, cultural } \\
\text { acquisition have a } \\
\text { certain foundation; } \\
\text { Culture has a long } \\
\text { history, profound; } \\
\text { Adjacent to Beijing } \\
\text { and Tianjin, the } \\
\text { geographical position } \\
\text { is superior. }\end{array}$ & $\begin{array}{l}\text { To use its own } \\
\text { advantages, under the } \\
\text { opportunity of the } \\
\text { coordinated } \\
\text { development of } \\
\text { beijing-tianjin-hebei. } \\
\text { using the Internet to this } \\
\text { huge publicity platform, } \\
\text { explore new directions } \\
\text { such as animation, film } \\
\text { and television play to } \\
\text { develop characteristic } \\
\text { culture industry of the } \\
\text { county. }\end{array}$ & $\begin{array}{l}\text { Advantage of the } \\
\text { characteristics of its } \\
\text { rich cultural resources, } \\
\text { has a long history, } \\
\text { sufficient to reduce the } \\
\text { gap with other } \\
\text { competitors, counties, } \\
\text { by competition into a } \\
\text { common "enemy", } \\
\text { improve the } \\
\text { competitiveness. }\end{array}$ \\
\hline $\begin{array}{c} \\
\text { Weaknes } \\
\end{array}$ & $\begin{array}{l}\text { is because of the } \\
\text { ciety, lead to too }\end{array}$ & $\begin{array}{l}\text { Weakness Opportunity } \\
\text { Strategy }(\mathrm{W}, \mathrm{O})\end{array}$ & $\begin{array}{l}\text { Weakness Threat } \\
\text { Strategy }(\mathrm{W}, \mathrm{T})\end{array}$ \\
\hline$s(W)$ & $\begin{array}{l}\text { many brand, become } \\
\text { a mere formality, } \\
\text { although established } \\
\text { brand, but positioning } \\
\text { fuzzy, } \\
\text { characteristics; Lack } \\
\text { of relevant personnel, } \\
\text { talent and decay; } \\
\text { System is not perfect, } \\
\text { investment } \\
\text { constitution is poor. }\end{array}$ & $\begin{array}{l}\text { Make full use of the } \\
\text { opportunity to reposition } \\
\text { brand as the } \\
\text { breakthrough point, } \\
\text { establish a high-end } \\
\text { brand, do have } \\
\text { characteristics, have } \\
\text { individual character } \\
\text { And use their own } \\
\text { geographical advantage, } \\
\text { rapid introduction of } \\
\text { talent and investment. }\end{array}$ & $\begin{array}{l}\text { Comb type, meticulous } \\
\text { division. Establish } \\
\text { long-term } \\
\text { introduction talent } \\
\text { cultivation mechanism. } \\
\text { Formulate and } \\
\text { improve relevant } \\
\text { systems, broaden the } \\
\text { investment channels, } \\
\text { attract } \\
\text { investment. }\end{array}$ \\
\hline
\end{tabular}

Conclusion: make full use of their own advantages, seize the opportunity to improve their own shortcomings, actively respond to challenges.

\section{HEBEI COUNTY CULTURAL INDUSTRY DEVELOPMENT STRATEGY PLANNING}

\section{A. Using the opportunity, the coordinated development of beijing-tianjin-hebei}

In comparison, the Beijing and Tianjin cities of the cultural industry is more developed, more abundant resources, and do better in the product planning, research and marketing. However, county cultural industry in Hebei province outstanding features, such as Quyang stone, Yuxian paper-cut, Wuqiang New Year pictures, Cangzhou martial arts, Wuqiao acrobatics, etc. In this opportunity, the characteristics of each county in Hebei province cultural industry should be actively docking with Beijing and Tianjin. Due to the Beijing and Tianjin on the cultural development is much stronger than both Hebei around, so when the docking, the county should, as far as possible to unite, be status equal, form partnerships. At the same time, the county should actively learn the Beijing and Tianjin cities of the advanced concepts and practices, using their own advantages of the area, low cost, on the system, policy, service and the Beijing and tianjin away gradient, attract production subject to their respective local cultural industry investment company, the development of beijing-tianjin-hebei prosperity together.

\section{B. Grasp accurate positioning, joint development}

Due to the regional brand is mostly on the basis of Hebei common historical and cultural development, resulting in each county's cultural brands are mostly similar, not characteristics.So, the development of the brand should be the first to cooperate in each county. For example, Quyang stone can be combined Wuqiang New Year pictures, vivid pictures of pictures moment on the stones, so that not only Wuqiang New Year pictures have new outlets, Quyang stone also has the more material.So that it is unified and independent, take the road of characteristic development, both common market and have their own cultural industry.

\section{Shaping the brand, high-end development}

Beijing-tianjin-hebei yanzhao culture has a long history, its main source is in Hebei province, so that the county should be authentic yanzhao culture as the core, combined with their respective characteristic culture of outstanding outstanding place, carries on the unique fusion processing, create a peculiar to each county high-end cultural industry, and then accordingly do everywhere, create each county unique high-end cultural industry, strive for common into the high-end market, do the real prosperity of the cultural industry.

\section{The establishment of the introduction of talent, training mechanism}

Talent is the core of the development of the industry, the development of any one industry is the introduction and cultivation of talent from the beginning. A key factor restricting the development of county characteristic culture industry in Hebei province is the lack of talents in relevant fields. So, at present, it is urgent to introduce and cultivate talents. Counties with their own cultural 
characteristics, formulate reasonable talent introduction mechanism, in a short period of time to attract lots of relevant personnel to their respective county development. In addition, in the long run, more should be done is the training of local talents. Counties can be alone to establish institute, can also be used with other county together to establish a common, do short-term and long-term talents of uninterrupted output, to ensure the good development of cultural industry.

\section{E. Formulate, optimize the relevant policies, establish a good investment system}

The development of the industry can not be separated from the support of funds, especially in the development of the industry, but also need a lot of money to support. At present, the relevant policy of each county in Hebei province is not ideal, there is no good investment system, and can't attract a large number of investment, the source of the funds also rely mainly on the government, the cultural industry developed provinces and cities county there is a larger gap. Therefore, the next Hebei Province, whether from the overall perspective or from the perspective of the county, should be based on their own cultural resources to develop and optimize the relevant policies, establish a good investment system to attract private investment. Counties can follow the following steps: first, research their own county characteristic culture, and to develop a unique cultural brands or slogan, and then based on the relevant policies, attract investment.

\section{CONCLUSIONS}

As a big cultural province of Hebei, in a culturally strong province of at the same time, needs the joint efforts of all aspects, as a pillar industry of Hebei culture county characteristic culture, is one part of the indispensable. Fundamentally, is to realize its own advantages and disadvantages, grasp the cultural industry of the future development direction, looking for accurate positioning, combined with their own advantages to adopt feasible measures, development of cultural industry, cultural strong province.

\section{ACKNOWLEDGEMENT}

This paper is the 2015 annual social science research and development of Hebei Province, based on the SWOT analysis and DEA model of Hebei province county characteristics and cultural industry development strategy research" part of the results (subject to the approval number: 201501938)"

\section{REFERENCES}

[1] Jia Yue. Research on the development mode of county characteristic culture industry in Hebei province [J]. Economic Forum, 2012,09:25-29.

[2] Li Yuling, Zhang Runqing, Han Yuequan. County of Hebei Province cultural characteristics of leading industry selection $[\mathrm{J}]$. Cooperation in economy and technology. 2014,18:22-23.

[3] Cai Ling, Xue Shengwen, Shen Zheyan.2015-2019, Hebei Province, the cultural industry investment analysis and forecast report [R].2015.

[4]CNNIC.2015 thirty-fifth times Statistical report on the development of China Internet network [R].2015.

[5] Du Fuguang, Liu Xiaochun, Li Wenrong. Based on the SWOT analysis of the cultural industry in hebei province location choice research [J]. Journal of bohai sea economic outlook, 2015 01:53-56.

[6] Chen Wanqin. The path of development of county characteristic industry in Hebei province and Its Revelation [J]. Economic Forum, 2014, (1): 30-33.

[7]Li Jianfeng, Hebei Province, province, province, the characteristics of cultural brand building research -- a case study of Shijiazhuang City, Chengde city and Qinhuangdao City, [J].Journal of border economy and culture, $2014 \quad 01: 18$ to 19 